\title{
Algorithm of creating an educational video film from the cycle "Clinical immunology and allergology"
}

\author{
K. Y. Gashynova, V. V. Rodionova, V. V. Dmitrichenko, O. S. Khmel, O. M. Kovalenko
}

\author{
Department of Occupational Diseases and Clinical Immunology \\ State establishment "Dnipropetrovsk Medical Academy of Health Ministry of Ukraine", Dnipro \\ *Corresponding author. E-mail: helesss1990@gmail.com
}

Paper received 20.10.18; Accepted for publication 26.10.18.

\section{https://doi.org/10.31174/SEND-PP2018-181VI75-04}

Abstract. The purpose was to create an educational video film from the topic "Immunopathogenesis of allergic asthma". Materials and methods: For creation an animated video film we used Google scholar, program Audacity 2.1.0., lisenced versions of Easy Paint Tool SAI, Photoshop CC 2017, Vegas Pro version 13.0 (64.0). The creation of the videofilm included searching for literature on the subject, writing a script, audio recording of the text, preparing graphic images, animation and combining small records into a holistic film with final rendering. Total duration of videofilm was $4 \mathrm{~min} 49 \mathrm{sec}$. The term of creating the film was about 1 month. Conclusions: Video films are an important additional material of the educational process, which makes it easier for students to understand the subject and manage with the high-quality educational material. Directly on the basis of the department it is possible to create educational video films independently with the necessary software and working skills. Creating a video film is a lengthy process that takes a certain amount of time and can limit the amount of product created.

Keywords: educational video film, clinical immunology and allergology, asthma.

Relevance: The high rates of development of medical science pose a difficult task for a medical student to find relevant and reliable information to prepare for classroom and extracurricular classes [1]. At the same time, the cycle of clinical immunology and allergology is quite complex and requires the assimilation of a large amount of new information in a short period of time. The teachers are faced with the problem of providing not only a general idea of the subject, but also to interest the student, to encourage him to prepare himself for sufficiently deep knowledge [2]. Students need to use a large number of information sources, but not always only text files can help the student to understand the whole range of immunological processes and their features.

There is a functional asymmetry of the hemispheres of the human brain, it is impossible not to take into account in the learning process [3]. It is proved that in different hemispheres different functions [3]. The right hemisphere is "responsible" for figurative thinking, for holistic perception, for the perception of spatial forms, and the left one for language, logic, work with signs [3]. In the absolute majority of people, the right hemisphere is included in the work upon acquaintance with new information [3] Therefore, for the successful development of knowledge, it is advisable to strengthen the visual-figurative component of the material, which is presented as a counterweight (in some cases) or a "support" of the abstract logical component is necessary [3]. Therefore, there will be a demand for methods that use figurative thinking of a student [3].

Purpose: to create an educational video film from the topic "Immunopathogenesis of allergic asthma".

Materials and methods: The creation of the video film included searching for literature on the subject, writing a script, audio recording of the text, preparing graphic images, animation and combining small records into a holistic film with final rendering. The search for literature was done using Google scholar. Audio recording of the text was done with help of the free program Audacity 2.1.0. Images were created using the Easy Paint Tool SAI, version 1.1.0, license number 010111131954, frame-byframe animation of images was done using Photoshop CC 2017, license number 2017.1.1 20170425.r.252 2017/04/25: 23: 00: 00 CL 1113967, combining video clips into a holistic film and final rendering was done in the Vegas Pro version 13.0 (64.0) license number 1TRB604-L3BC-J0H5.

Results and discussion:

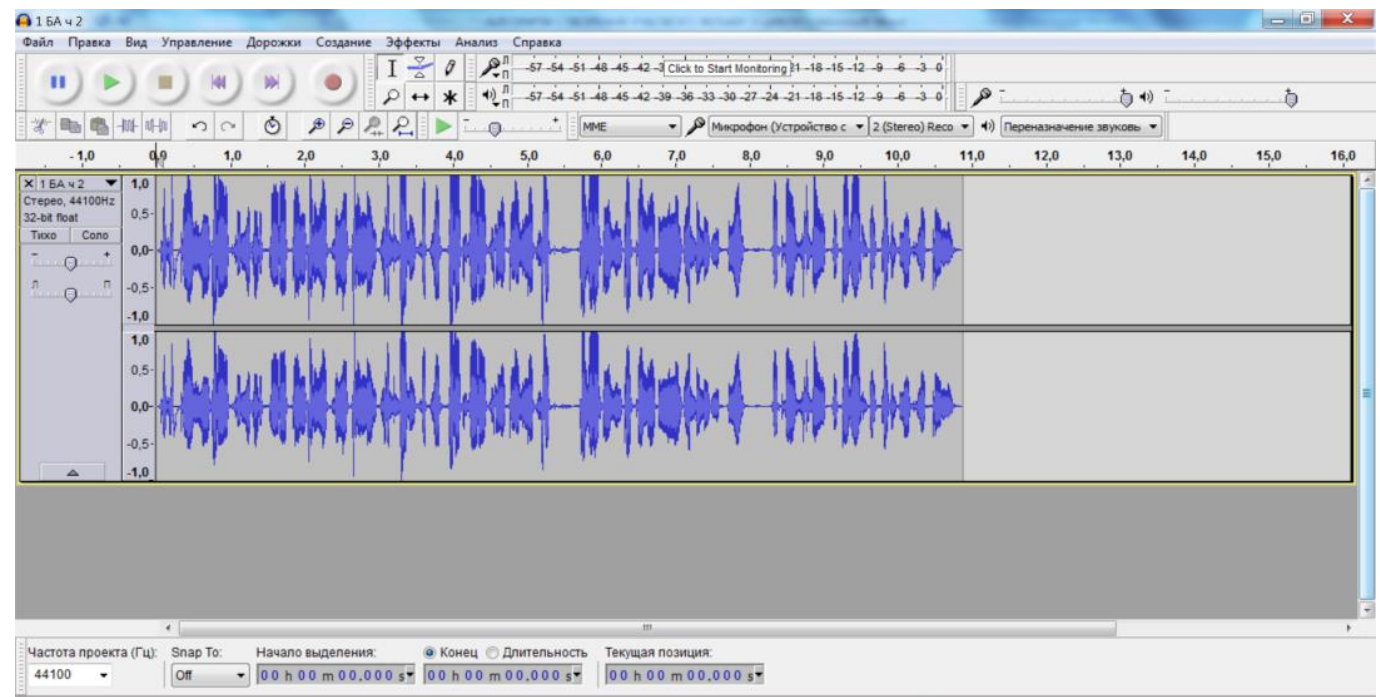

Fig. 1- the general view of the audio recording sentence after processing in the program Audacity 2.1.0 
The film was based on a script. In order to write the script, 37 sources of literature, both English and Ukrainian, were analyzed, on the basis of which scriptwriting was created. The text was read in one sentence and recorded using the Audacity program. Then in this program the signal was normalized, noise cancellation, volume increase and final recording of audio were held (Pic. 1).

Next, in the Photoshop CC 2017 program a pre-created PSD image file with painted cells and a back background was opened. All images were schematic, they were ac- companied by inscriptions for better assimilation of information. Each moving element was depicted on a separate layer. For the purpose of better visual perception, important objects such as cells and cytokines had a more vivid color, and the background was more monochromatic and calmer. The location of objects was carried out according to the composite rule of thirds. The image size was 2400 pixels at 3200 pixels, that is, the standard aspect ratio of $3 * 4$, a resolution of 300 dpi. (Pic. 2).

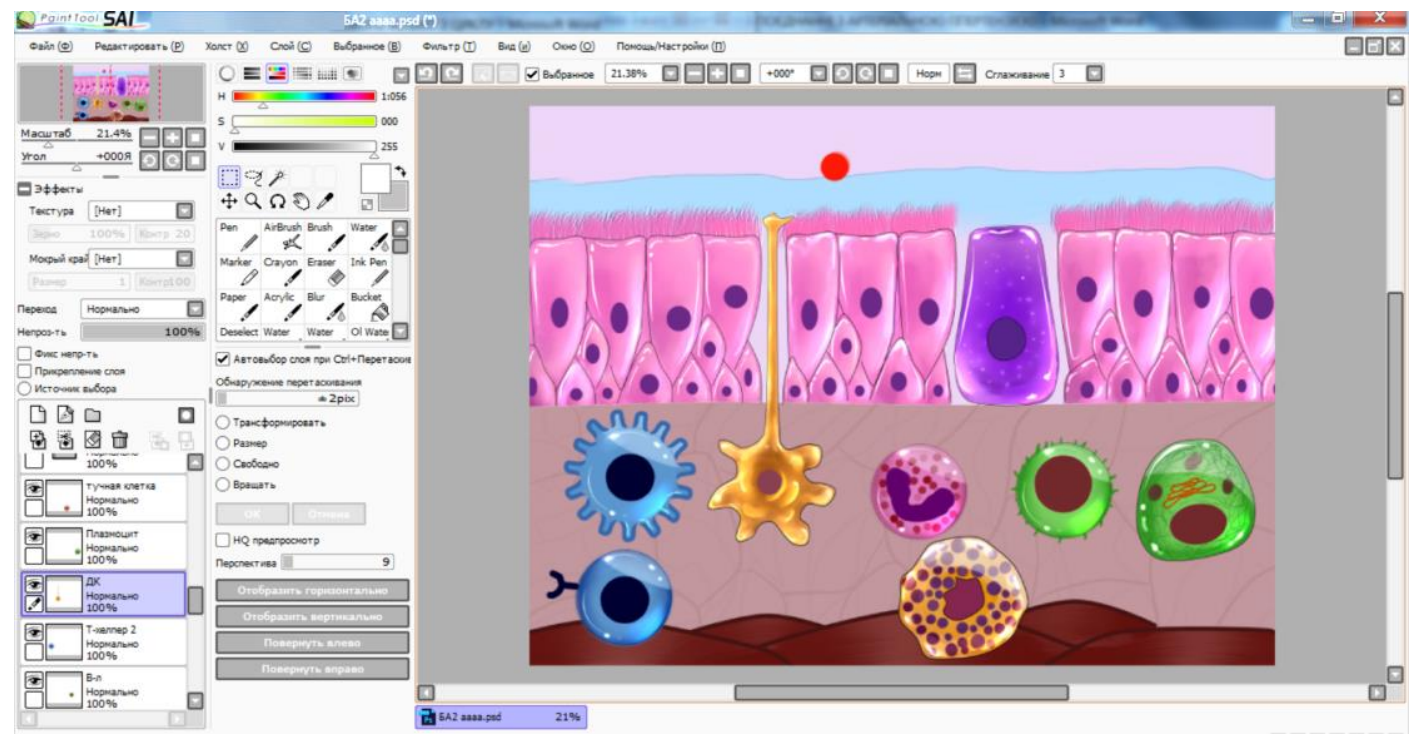

Fig. 2 - General view of the graphic file in Easy Paint Tool SAI 1.1.0

With help of frame-by-frame animation, the Photoshop CC 2017 program was created movement of objects and then frames were synchronizing with text. First, the keyframes were created by enabling or disabling a specif- ic layer, then adding intermediate frames to synchronize and smooth motion of the animated objects. The frame length was $0.1 \mathrm{~s}$. (Pic. 3).

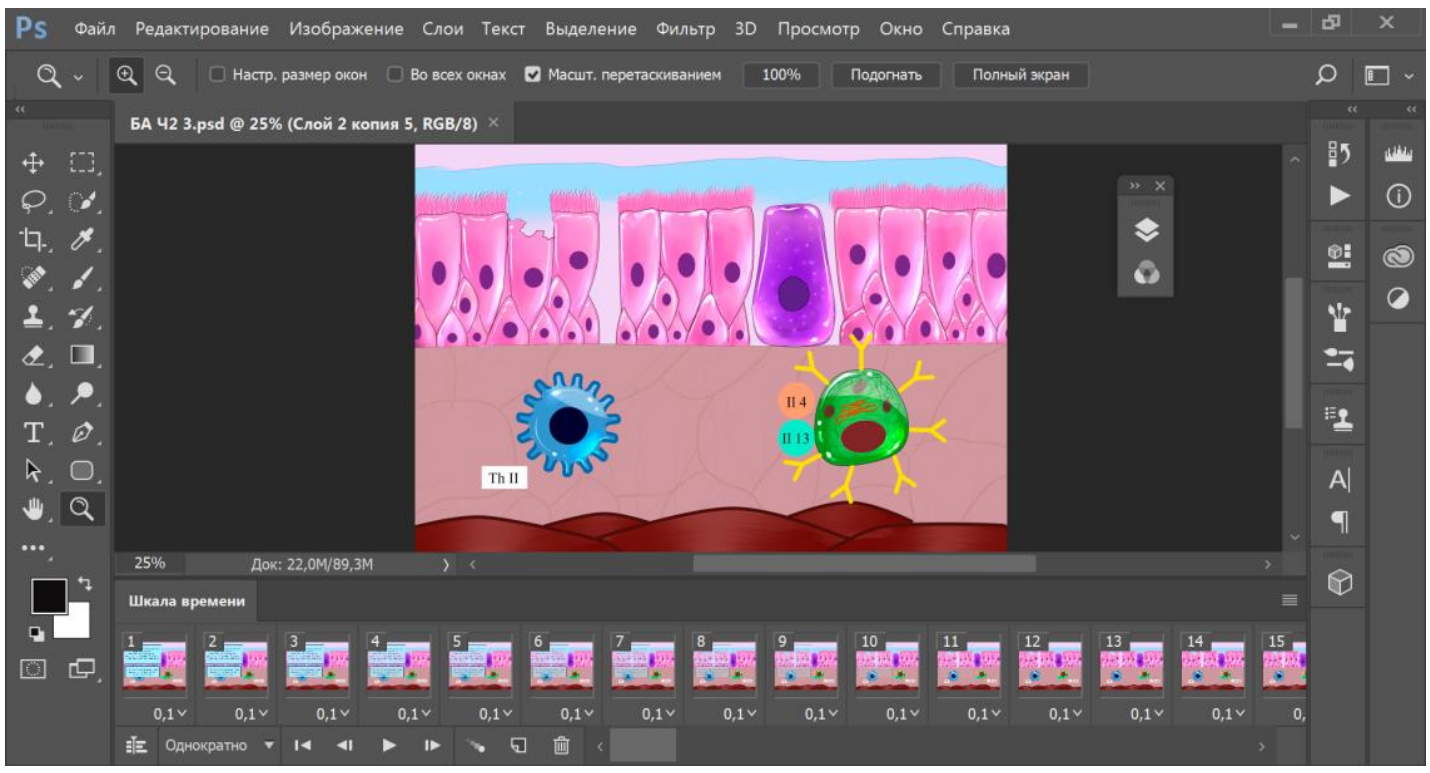

Fig. 3 - General view of a frame-by-frame animation graphic in Photoshop CC 2017

Next, using the "Convert In Video Time Scale" feature, the animated picture was converted into a video clip to which audio text was added and the final synchronization took place (Pic. 4). 


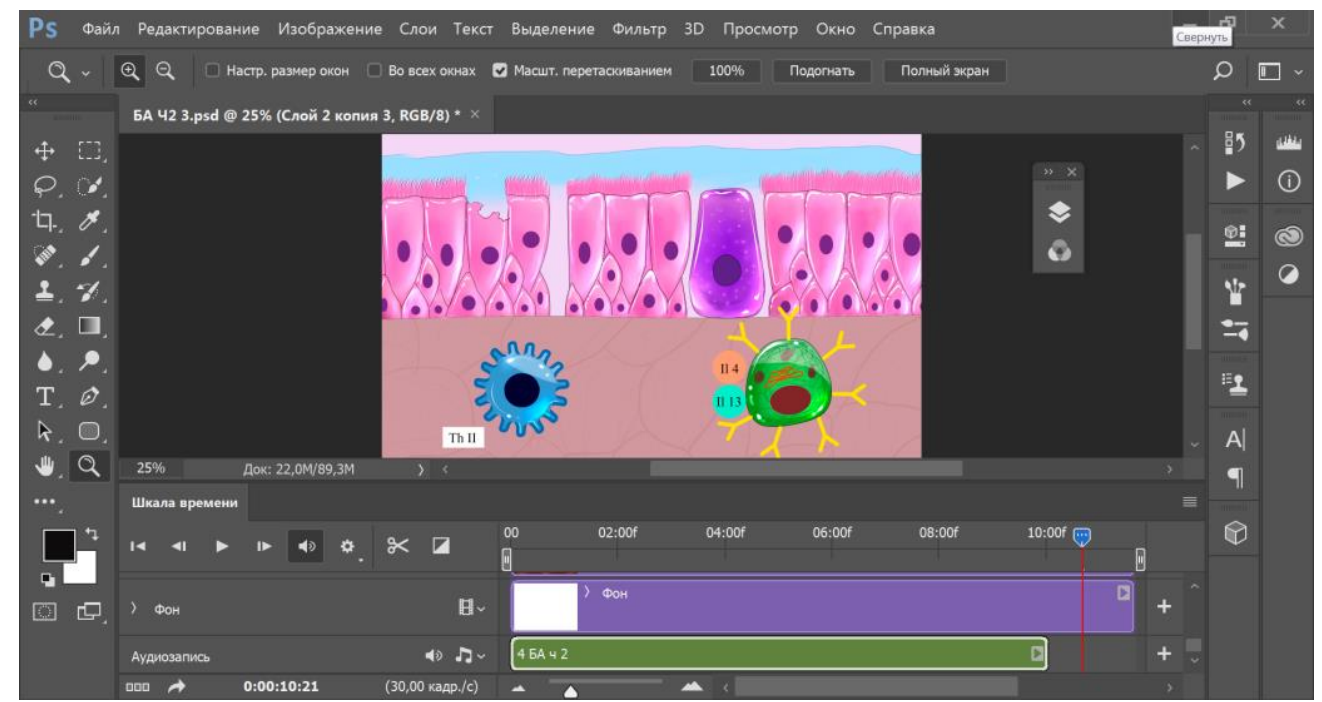

Fig. 4 - Adding audio to a graphic file converted to a video clip in Photoshop CC 2017

Saving the video file was done using the sequence of was saved in mp4 format, the image size was $1200 * 1600$ commands: File - Export - Export video - Save. The file pixels, with a frame rate of $30 \mathrm{fps}$ (Pic. 5).

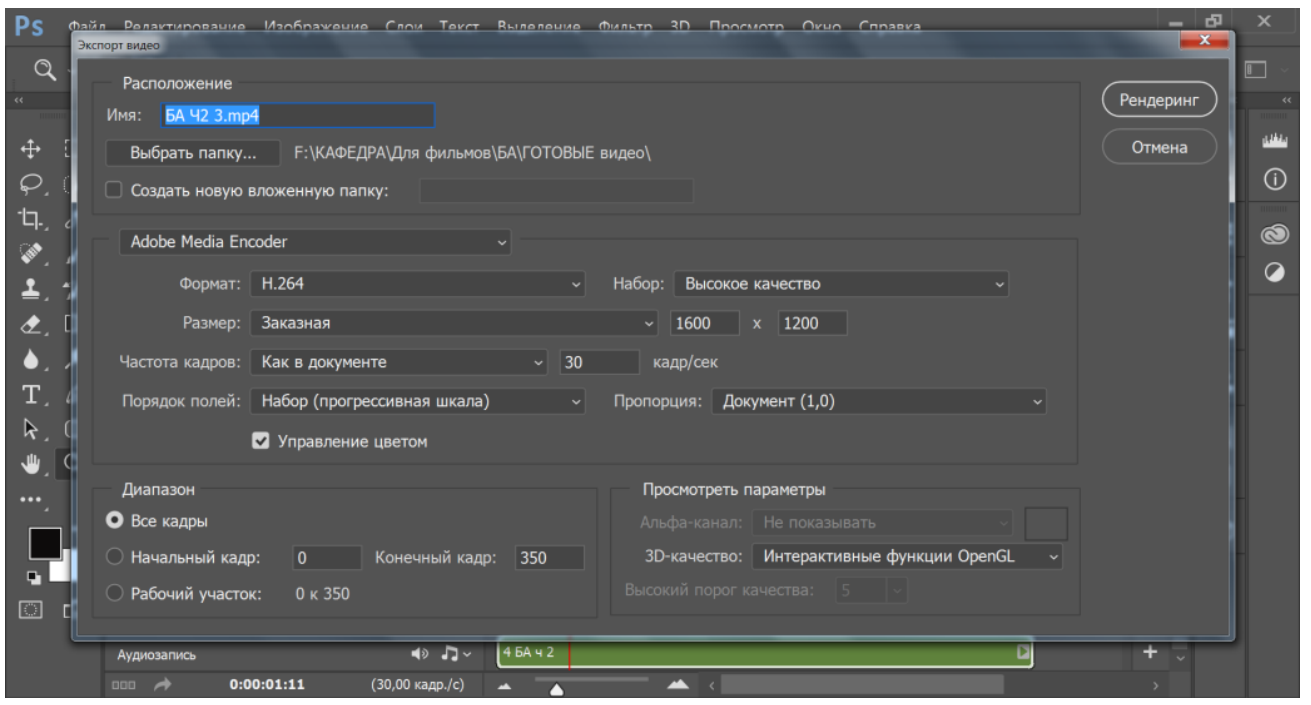

Fig. 5 - Saving video clip in Photoshop CC 2017

A series of video clips, a total of 25 records, lasting from 3 seconds to 32 seconds, were sequentially opened in the Vegas Pro version 13.0, followed by a final review of the file, file fix, and final rendering. Total video duration was 04 min $49 \sec$ (Рис. 6).

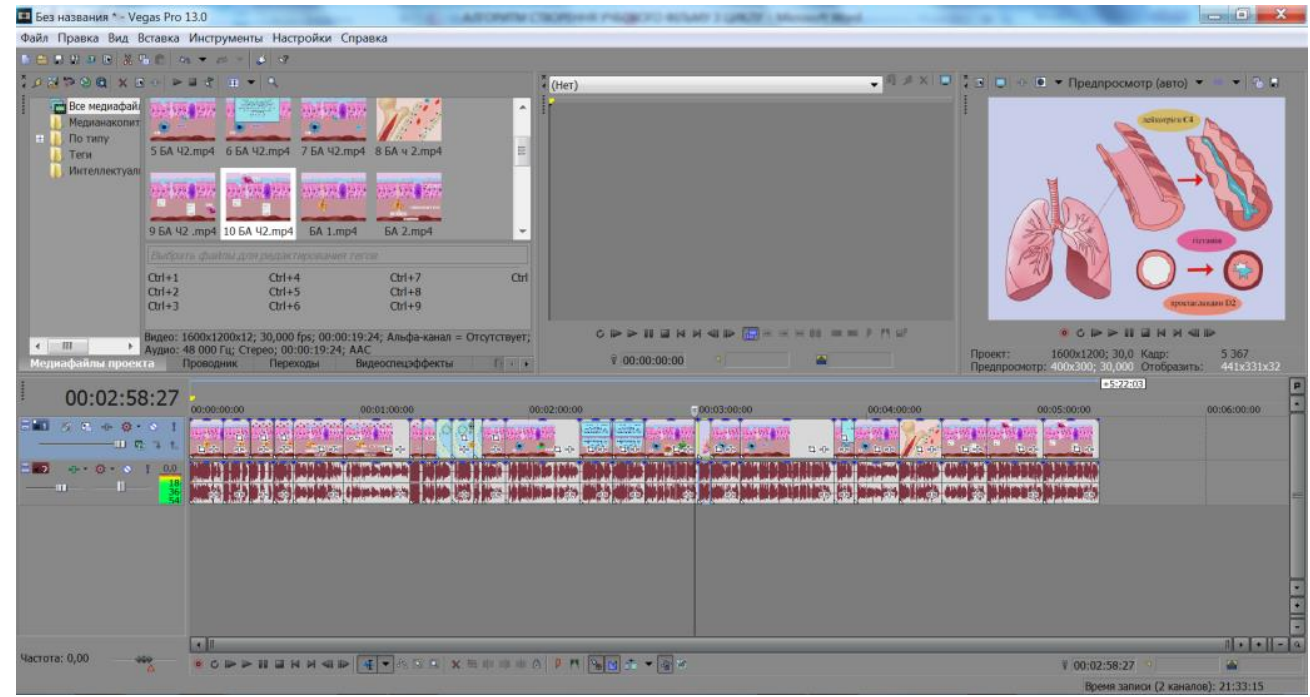

Fig. 6 - Creating a finished educational film in the Vegas Pro program 
The term of creating the film was about 1 month. Longest processes were drawing images and creating animations. Creating an animation takes a lot of time due to the long duration of rendering the animation into an animated video clip and saving it - rendering of 32 seconds of film, for example, took about 47 minutes. The overall rendering of the final animated film lasting 4 minutes 49 seconds took 6 hours 24 minutes. The presence of these flaws may limit the creation of animated videos.

\section{Conclusions:}

1. Video films are an important additional material of the educational process, which makes it easier for students to understand the subject and manage with the high-quality educational material.

2. Directly on the basis of the department it is possible to create educational video films independently with the necessary software and working skills.

3. Creating a videofilm is a lengthy process that takes a certain amount of time and can limit the amount of product created.

\section{REFERENCES}

1. Гашинова К. Ю., Дмитриченко В. В. Internet як джерело інформації при підготовці до занять. Матеріали XIV Bceукраїнської науково-практичної конференції з міжнародною участю, присвяченої 60-річчю ТДМУ сучасні підходи до вищої медичної освіти в Україні (з дистанційним під'єднанням ВМ(Ф)НЗ України за допомогою відеоконференц-зв'язку), 18-19 травня 2017 року. Тернопіль: ТДМУ «Укрмедкнига», 2017. С. 28-30.
2. Родіонова В. В., Коваленко О. М., Ніколаєнко-Камишова Т. П., Собко С. В., Хмель О. С. Досвід підготовки студентів до участі у всеукраїнській студентській олімпіаді 3 клінічної імунології та алергології (підсумки викладачів та погляд студентів). Медична освіта. 2016. №3. С. 78-81.

3. Безуглий Д. Прийоми візуального подання навчальної інформації. Фізико-математична освіта. 2014. Вип. 2. С. 7-15.

\section{REFERENCES}

1. Gashinova K. Yu., Dmitrichenko V. V. Internet as a source of information in preparation for the classes. Materials of the XIV All-Ukrainian Scientific and Practical Conference on International Participation devoted to the 60th anniversary of the TDMU Modern approaches to higher medical education in Ukraine (with the remote connection of VM $(\mathrm{F}) \mathrm{NZ}$ of Ukraine via videoconferencing), May 18-19, 2017 year Ternopil: TDMU "UkrmedkNiga", 2017. P. 28-30.

2. Rodionova V.V., Kovalenko O.M., Nikolayenko-Kamyshova
T.P., Sobko SV, Khmel O.S. Experience of preparation of students for participation in the All-Ukrainian Student Olympiad on Clinical Immunology and Allergology (results of teachers and the view of the students). Medical education. 2016. №3. Pp. 78-81.

3. Bezuglyj D. Receptions of visual presentation of educational information. Physical-mathematical education. 2014. Issue 2. 7-15 pp. 